\title{
Between change and persistence : Reżā Julā'i's short story Miti-Jenn as a mirror of social developments in Iran
}

\author{
Nünlist, Tobias
}

DOI: https://doi.org/10.1515/9783110399882-008

Posted at the Zurich Open Repository and Archive, University of Zurich ZORA URL: https://doi.org/10.5167/uzh-143348

Book Section

Published Version

Originally published at:

Nünlist, Tobias (2017). Between change and persistence : Reżā Julā’i’s short story Miti-Jenn as a mirror of social developments in Iran. In: Sheikhzadegan, Amir; Meier, Astrid. Beyond the Islamic Revolution : Perceptions of Modernity and Tradition in Iran before and after 1979. Berlin: De Gruyter, 155-176.

DOI: https://doi.org/10.1515/9783110399882-008 


\section{Worlds of Islam - Welten des Islams - Mondes de l'Islam}

Im Auftrag der Schweizerischen Asiengesellschaft On behalf of the Swiss Asia Society Au nom de la Société Suisse-Asie

Edited by Bettina Dennerlein Anke von Kügelgen

Silvia Naef

Maurus Reinkowski Ulrich Rudolph

\section{Volume 8}




\section{Beyond the Islamic Revolution}

Perceptions of Modernity and Tradition in Iran before and after 1979

Edited by Amir Sheikhzadegan and Astrid Meier

\section{DE GRUYTER}


This publication was made possible due to the support of Swiss Academy of Humanities and Social Sciences (SAGW).

Schweizerische Akademie der Geistes- und Sozialwissenschaften Académie suisse des sciences humaines et sociales Accademia svizzera di scienze umane e sociali Academia svizra da scienzas umanas e socialas Swiss Academy of Humanities and Social Sciences

ISBN 978-3-11-039959-2

e-ISBN (PDF) 978-3-11-039988-2

e-ISBN (EPUB) 978-3-11-040005-2

ISSN 1661-6278

\section{Library of Congress Cataloging-in-Publication Data}

A CIP catalog record for this book has been applied for at the Library of Congress.

\section{Bibliographic information published by the Deutsche Nationalbibliothek}

The Deutsche Nationalbibliothek lists this publication in the Deutsche Nationalbibliografie; detailed bibliographic data are available on the Internet at: http://dnb.dnb.de.

(c) 2017 Walter de Gruyter GmbH, Berlin/Boston

Cover image: Parastou Forouhar, "Red + Green III_C"

Typesetting: jürgen ullrich typosatz, Nördlingen

Printing and binding: $\mathrm{CPI}$ books $\mathrm{GmbH}$, Leck

@) Printed on acid-free paper

Printed in Germany

www.degruyter.com 


\section{Table of Contents}

Notes on Transliteration - VII

Amir Sheikhzadegan and Astrid Meier

Introduction - 1

\section{Part I: Main Intellectual Trends}

Ramin Jahanbegloo

Intellectuals and Society in Iran since $1953-17$

Amir Sheikhzadegan

The Trajectory of the 1953 Military Coup and the Course of Liberal Islam in Iran:

A Sociological Analysis — 31

Katajun Amirpur

Constructing and Deconstructing Othering: Polycentrism versus

Westoxication in Iran -60

\section{Part II: The Voices of the Less Visible}

Roswitha Badry

Insurmountable Hurdles to the Countering of Patriarchal Gender Discourse under a Clerical Oligarchy? Experiences of (Islamic) Feminists in the Islamic Republic of Iran (1979-2009) — 89

Erika Friedl

Heirs of Modernity in Rural Iran — 112

\section{Part III: Social Change in the Mirror of Art}

Katja Föllmer

The Rebellious Man and the Courageous Woman: Social Criticism and Gender Relations in Iranian Film Production before and after the Islamic

Revolution - 131 
VI _ Table of Contents

Tobias Nünlist

Between Change and Persistence: Reżā Julā'i’s Short Story Miti-Jenn as a Mirror of Social Developments in Iran — 155

Note on Contributors -177

Index of Names and Places 179 


\section{Notes on Transliteration}

Throughout this book, the transliteration of Persian names and terms follows the system of the Encyclopaedia Iranica (www.iranicaonline.org/pages/guidelines). Arabic words are transliterated according to the norms of the International Journal of Middle East Studies.

In cases of proper names that have common English spellings, such as places and individuals, we opted for the English spelling (e.g. Tehran, Shiraz, Reza Shah, Khomeini, and Ahmadinejad instead of Tehrān, Širāz, Reżā Šāh, Komeini, and Aḥmadinežād). The same holds for Arabic and Persian terms that have entered English lexicons (e.g. mullah, Ayatollah, and Khan instead of mullā, Āyatollāh, and Kān), as well as for the names of Iranian scholars who have published in languages other than Persian.

Dates are given according to the Common Era calender. In the case both the Islamic (Hijri) and the Common Era calender are used, dates appear in the following form: Hijri/Common Era. The common form for Hijra dates is the solar calendar, with the lunar ones being marked with the abbreviation "h.q." (for Hijri Qamari). 
Bereitgestellt von | UZH Hauptbibliothek / Zentralbibliothek Zürich Angemeldet Heruntergeladen am | 21.07.17 13:33 


\title{
Between Change and Persistence: Reżā Julā'i's Short Story Miti-Jenn as a Mirror of Social Developments in Iran
}

\begin{abstract}
This paper explores various aspects relevant to an understanding of current developments in Iranian society through Reżā Julā'i's short story Miti-Jenn (published in Tālār-e Tarab-k̄âneh, 1371/1992) ${ }^{1}$. Born in Tehran in 1950, Julā'i is a well-known writer who has won several literary prizes.

Julā'i frequently situates his stories and novels (e.g. Su'-e qașd be dāt-e homāyuni) in the Qājār period (1796-1925). Having had a closer look at his œuvre, however, it becomes impossible to ignore the present-day implications of his interpretations. The short story Miti-Jenn allows us to identify both constant and changing elements in the development of modern Iranian society between the Constitutional Revolution (1905-11) and today.

This analysis will center on the tensions between reason and superstition, and between reality and the surreal. It will focus on Reżā Julā'i's use of traditional demonical beliefs as a key to understanding some of the central problems of present-day Iran.
\end{abstract}

\section{Reżā Julā'i: Introductory Remarks}

Reżā Julā'i is a firmly established modern Iranian prose-writer and winner of several literary prizes. Hasan Mir-'Ābedini discusses him in his study of modern Persian prose, ${ }^{2}$ and Yusuf 'Alikāni includes him in his collection of ten writers of the so-called third generation (nasl-e sevvom). ${ }^{3}$

In the West, however, Julā'i has gone virtually unnoticed, even by researchers. Kamran Talattof in his introduction to modern Persian literature simply mentions his name. ${ }^{4}$ In Ein Fenster zur Freiheit, Mohammad H. Allafi at least gives

1 All internet sources mentioned in this article were last consulted in January 2010.

2 Mir-'Ābedini 1999: 934-935, 986-994, 1106, 1233.

3 'Alik̄āni 2001: 35-50.

4 Talattof 2000: 109. 
some brief information about his biography and œuvre. ${ }^{5}$ Other reviews of Persian literature by Western scholars were published before the Islamic Revolution of 1978-79 and consequently could not include any references to Julā'i.

Julāi himself remains discreet about his biography and prefers to be known through his literary texts: "If you want to know me, read my novels and short stories attentively. Biographical facts do not matter." ${ }^{6}$ His opinion gives a first impression of the author's character and opinions. While respecting his reservations, I still consider it useful to give a short overview of Julā'i's biography and œuvre. The following summary is largely based on various Persian internet sources, though special attention is paid to the biographical sketch published on Julā'i's personal website. ${ }^{7}$

\section{Biography and Cuvre}

Julā'i was born into a Tehrani middle-class family in 1329/1950. Having graduated from Alborz High School, he commenced studies at the University of Shiraz in 1347/ 1968. At the same time, he began to write literary texts which he published in various reviews. In 1353/1974 he obtained a BA degree in economics at the University of Shiraz, having undergone many challenges and discouraging setbacks, as he sardonically comments. He published his first collection of short stories, Hekāyat-e selseleh-ye pošt-kamānān (The saga of the bent ones), in 1362/1983.

These early writings were not favorably received, but the situation changed radically with the publication of Jämeh be kunāb (Blood-soaked clothes) in 1368/ 1989, a collection of twelve short stories. The book won the Louh-e zarrin literary award in 1370/1991 as well as a distinguished prize for the best collection of short stories in post-revolutionary Iran. Julā'i, regarded meanwhile as an important figure on the Iranian literary scene, is respected as a writer with a fine command of Persian who cultivates a new, personal style.

As well as being an author, Julā'i remains active as a translator, reader and publisher. Thanks to these activities, he is financially independent. In 1369/1990,

5 Allafi 2000: 24-29, 30-50 (translation of an excerpt of Julā'i’s novel Su'-e qașd be $\underline{\text { datt-e }}$ homāyuni).

6 Personal communication from Julā'i (e-mail, February 2002).

7 Julā'i's personal website: www.rezajoulaee.com. Biographical information provided by his daughter A. Julā'i: http://www.rezajoulaee.com/Biography/DaughterWrite.htm; Yusuf 'Aliknāni interview with R. Julā'i: http://sokhan.com/articles.asp?ID=31010; Interview with R. Julā'i, in: Qābil. Majalle-ye dāstān-o še'r (http://www.ghabil.com/article.aspx?id=219); see also: Nünlist 2005: 47-51. 
he published the novel Šab-e zolmāni-ye Yaldā (The dark Yaldā-night) and the story Hadit-e dord-kešān (The dregs-drinkers' tale) in one volume. In 1371/1992 Tālār-e țarab-k̄āneh (The Tarab-kāneh-Hall) followed, a collection of twelve short stories written between 1365/1986 and 1368/1989 which includes Miti-Jenn, the subject of the present article. The author considers Su'-e qașd be dāt-e homāyuni (The attack on the life of His Majesty; 1374/1995) to be one of his most important texts.

In 1376/1997, the novel Jāvedānegān (The everlasting ones) was published, followed in 1377/1998 by another collection of ten short stories entitled Nastaranhā-ye șurati (Pink dog roses). Bārān-hā-ye sabz (Green rains; 1380/2001), a collection of six short stories, won the Yaldā Literary Award. The author emphasizes that his latest novel Simāb-o kimiyā-ye jān (Quicksilver and the alchemy of the soul; 1381/2002) illustrates well the deeper meanings of his literary œuvre in general. Although Julā'i is a successful writer of novels, his short stories are equally important. ${ }^{8}$

Conditions in Iran at present do not allow Julā'i to publish his texts. The author announced another novel in 2006 entitled Kiyābān-hā-ye barrāq-o nimehtārik-e šabi bārān-zade (The shining streets of a dim rainy night), but it was not available in 2010, when the present article was written. The following list gives a chronological overview of Julā'i's literary œuvre:

1. Hekāyat-e selseleh-ye pošt-kamānān ${ }^{9}$

$1362 / 1983$

(a collection of short stories)

2. Jāmeh be kun-ā $b^{10}$

$1368 / 1989$

(a collection of eleven short stories)

3. Šab-e zolmāni-ye Yaldā-o Hadiț-e dord-kešā $n^{11}$

$1369 / 1990$

(a novel and a long story [dāstān-e boland]).

4. Tālār-e țarab-kāneh ${ }^{12}$

1371/1992

(a collection of twelve short stories)

5. Su'-e qașd be dāt-e homāyuni ${ }^{13}$

$1374 / 1995$

(a novel)

6. Jāvedānegān ${ }^{14}$

$1376 / 1997$

(a long story)

8 Interview with Reḍā Julā’i published at http://www.ghabil.com/article.aspx?id=219; p. 3.

9 The saga of the bent ones.

10 Blood-soaked clothes.

11 The dark Yaldā-night and the dregs-drinkers' tale.

12 The Țarab-k̄anneh-Hall.

13 The attack on the life of His Majesty.

14 The everlasting ones. 
7. Nastaran-hā-ye șurati ${ }^{15}$

$1377 / 1998$

(a collection of ten short stories)

8. Bārān-hā-ye sabz ${ }^{16}$

$1380 / 2001$

(a collection of six short stories)

9. Simāb-o kimiyā-ye jān ${ }^{17}$

$1381 / 2002$

(a novel)

\section{Literary Style and Technique}

A thorough analysis of Julā'i's writing style is beyond the scope of an initial survey. Some general remarks on his literary and technical preferences, however, allow us to situate him in a broader cultural context. From 1360/1981, Julā'i was employed as a reader in a Tehrani publishing house where he was in daily contact with other writers, Mạ̣mud Doulatābādi, Reżā Barāheni and Hušang Golširi among them. He benefited greatly from this literary milieu which stimulated his own artistic work. ${ }^{18}$ He attended Golširi's writing classes repeatedly in 1364/1985, but although Julā'i enjoyed Golširi's encouragement, he avoided this highly competitive literary milieu and preferred to develop his own style. In so doing, Julā'i was influenced by different South American writers. Translations into Persian made him familiar with Julio Cortázar, Jorges Luis Borges, and Gabriel García Marquez. ${ }^{19}$ The writer was fascinated by Borges' and Marquez' efforts to bridge the ontological gap between reality and an imaginary world.

Julā'i dealt in several texts with the introduction of the medium of film into Iran at the beginning of the twentieth century. Deeply impressed by attempts to remove the boundaries between reality and imagination in Iranian cinema, he tried to apply these techniques to his own literary texts later on. By doing so, Julā'i hoped to launch a process of reciprocal influence between film and literature. Convinced that this new medium allowed the writer to express complicated situations in simple images, he profited from its succinct language. The short stories

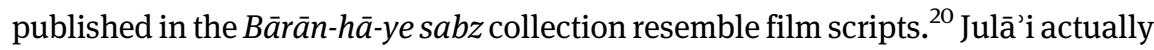

15 Pink dog roses.

16 Green rains.

17 Quicksilver and the alchemy of the soul.

18 Interview with Reżā Julā'i by Yusuf 'Alik̄āni: 5-6, http://sokhan.com/articles.asp?ID=31010.

19 An international congress organized by the "Iranian Literature Foundation" from 26 May to 1 June 2007 in Tehran and Eșfahān was dedicated to the study of Latin American literature and its influence on Iranian writers (Kongre-ye bayn ol-melali-ye Adabiyyāt-e Āmrikā-ye Lātin).

20 Interview with Reżā Julā’i by Yusuf 'Aliknāni: 9-10, http://sokhan.com/articles.asp?ID=31010. 
collaborated on various film projects during a period of about eight to ten years. Dāriuš Mehrju' ${ }^{21}$ intended to produce a film entitled Kārāgāh (The police inspector), based on Julā'i's short stories Sayl-āb (The flood) and Parvandeh (The file), both published in Jāmeh be kunāb. Unfortunately, the film was never completed.

Other projects failed for different reasons, e. g. politically motivated interventions or personal disagreement among the partners. The writer is particularly concerned about the suppression of a film project dealing with the CIA-supported coup against Mohammad Moṣaddeq in the summer of 1332/1953. The film should have been broadcast as a TV soap opera under the title Täbestān-e abri-ye 32 (The cloudy summer of [13]32), but the project was stopped at a very advanced stage under circumstances that were never explained. ${ }^{22}$

Although highly interested in modern artistic genres, Julā'i often locates his texts in the past. His latest novel, Simāb-o kimiyā-ye jān, is situated in the context of the Mongol invasion of Iran, ${ }^{23}$ even though in his earlier writings, the author showed a special interest in the Qājār period (1796-1925). ${ }^{24}$ This period even influenced his style: The vocabulary of the majority of his short stories published in Jāmeh be kֵunāb, Tālār-e tarab-k̄āneh, and in his novel Su'-e qașd be dāt-e homāyu$n i,{ }^{25}$ was archaic. There are expressions taken directly from Arabic, the syntax is intricate, the style lush, and ornate terms current in Iran in the second half of the nineteenth century are employed. This stylistic combination makes some of Julā'i's texts less accessible to the general public. The author writes primarily for an elite

21 Dāriuš Mehrju'i was born in 1318/1939. In the West he is best known for his film Gāv (The Cow; 1348/1969). For further information see Wakeman 1987/1988: 2:663-669; and "Internet Movie Database": http://www.imdb.com/name/nm0576529/.

22 Interview with R. Julā'i by Yusuf 'Alikāni: 9, http://sokhan.com/articles.asp?ID=31010.

23 The Mongols overran and devastated Iran at the end of the twelfth and the beginning of the thirteenth centuries C.E. In Simāb-o kimiyā-ye jān, Julā'i analyses the nightmares of a painter who flees from the vengeance of the Mongol Khan. In a short overview of the text, literary critic H. Mir'Ābedini (see: http://sokhan.com/articles.asp?ID=3690660001) refers to several points shared between Simāb-o kimiyā-ye jān and Dante's Divina Commedia. Both texts describe a fictive journey through the human soul. The atrocities committed by the Mongols when attacking Iran form the cruel background of Julā'i's analysis of the darker aspects of the human psyche.

24 Therefore critics often asked Julā'i a question that he has now placed on the entry page of his personal website: "Čerā dar-bāreh-ye doureh-ye Qājār mi-nevisi?" ("Why are you writing about the Qājār period?”). See: Personal website of the author: www.reza joulaee.com. Julā'i became familiar with the Qājār period in two different ways: His grandmother frequently told him anecdotes about this dynasty when he was a child. Later, he consulted scientific studies of this period and the social and historical developments in Iran during the nineteenth century (personal communication from the author; Tehran, February 2005).

25 The novel Su'-e qașd be dāt-e homāyuni analyses the political and social motivations of a group of Iranian intellectuals plotting an attack on the life of Mohammad 'Ali Shah in 1908. 
readership. Because Julā'i frequently situates his novels and short stories in a specific historical context, Mir- 'Ābedini and Allafi ascribe to him an important role in the development of the historical novel in modern Persian prose fiction. ${ }^{26}$

But Julā'i's literary texts are not primarily concerned with the past. If he deals with the past, it is out of a conviction that the past has lasting effects on the present. Because of all too frequent cruel invasions during the last millenium, the author argues, the "Orientals" (šarqi-hā) have suffered hard setbacks and have been helpless victims of indescribable atrocities. In fact, their enemies have wrought havoc with their inner and outer lives. ${ }^{27}$

Deeply interested in exploring the psychological dimensions of human existence, Julā'i considers the honest description of the real self a complicated process. Because all too frequently, looking into the chasm of one's own being is too difficult a task, one shrinks back from removing the veil which conceals one's own inner abyss. ${ }^{28}$

The present article sets out to illustrate the writer's aims and convictions through an analysis of his short story Miti-Jenn. His text provides us with a deep insight into fundamental aspects of the historical, economic, and intellectual developments of Iranian society at the beginning of the twentieth century. A closer look will allow us to identify a series of elements which characterize Iran to this day.

\section{The Short Story Miti-Jenn: an Analysis}

\section{Main Protagonists and Historical Context}

The short story Miti-Jenn, published in the collection Tālār-e tarab-kaneh along with eleven other stories in 1371/1992, was written between 1365/1986 and 1368/ 1989. As is the case with many other so-called short stories (dāstān-e kutāh) by Iranian writers, the reader is confronted with a rather long text of about twenty-

26 Mir-'Ābedini 1999: 3;986-994; Allafi 2000: 25.

27 Author's personal website: www.rezajoulaee.com, introductory page:

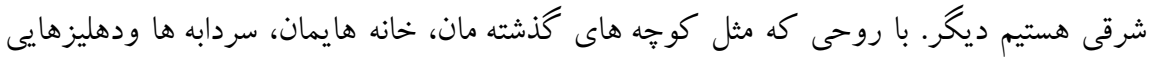

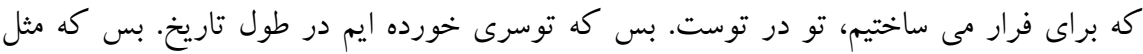

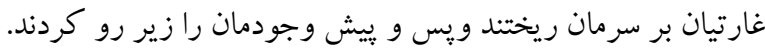

28 Author's personal website: www.rezajoulaee.com, introductory page:

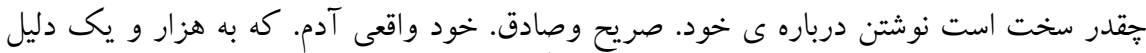

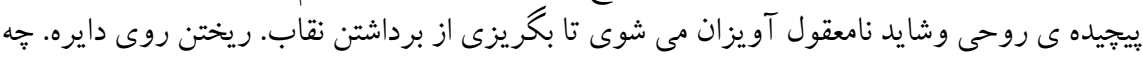

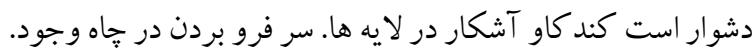


five pages. The text is divided into three parts of seven to nine pages each. These parts are simply numbered 1 to 3 , without subtitles.

The plot primarily develops through the interaction of two protagonists, Jahāngir-Khan and the narrator. Their relationship is complicated by the appearance of a third being called Miti-Jenn.

The text describes Jahāngir-Khan as a monavvar ol-fekr, an intellectual. ${ }^{29} \mathrm{He}$ was sent to Europe (farang) to study the technology of steam engines, a detail alluding to the technological backwardness of Persia at the end of the nineteenth century. His two aunts who consider a prolonged stay in the West an act of kofr (religious unbelief) oblige Jahāngir-Khan to return to his home country after completing his studies.

Back in Tehran, however, Jahāngir-Khan does not find an occupation that corresponds to his technological training. Julā'i adds mockingly that in those days, just two steam engines existed in Iran (mamālek-e mahruseh). The first one, a steam coach owned by the late Mozaffar al-Din Shah, ${ }^{30}$ awaited the end of its days in the Dušān-Tappeh Building, ${ }^{31}$ while the other, belonging to Otor-Khan Rašti and nicknamed "Keh-keh-barin", was rusting away under ten-month rainfalls in Gilan. ${ }^{32}$

Given the circumstances, Jahāngir-Khan begins to translate French novels into Persian, but he cannot publish them. ${ }^{33} \mathrm{He}$ is therefore obliged to abandon his cultural projects. Together with the narrator, he turns to the highly esteemed profession of journalism (šoğl-e šarif-e jarideh-negāri), as Julā'i explains with an emphatic undertone. ${ }^{34}$

Clearly situated in the period of the Constitutional Revolution (1905-1911), the story emphasizes the extremely confused (mağšuš) situation in Tehran. ${ }^{35}$ The Shah alternates between controlling the country by coercive measures and trying to win over the newly established parliament (majles) by flattery. The people (kalā'eq-e ebn ol-vaqt) sometimes adhere to the defenders of the šari' $a$ (mašru'eh), and other times accept the kabābs offered by the constitutionalists (mašruteh).

29 Miti-Jenn 32.6-10.

30 The Qājār ruler Moẓaffar al-Din Shah (1853-1907) reigned from 1896 to 1907.

31 Dušān-Tappeh: an area situated in the east of Tehran; during the Qājār period, it was the location of a hippodrome; one of the city gates of old Tehran was called Dušān Tappeh (Dehkodā 1377/1998).

32 Miti-Jenn 32.10-15.

33 For the importance of the translation movement in the second half of the nineteenth and the first half of the twentieth century in Iran, see: Balaÿ/Cuypers 1983: 27-33.

34 Miti-Jenn 32.16f. The name Jahāngir-Khan probably alludes to the well-known journalist Mirzā Jahāngir-Khan Širāzi (1875-1908), the editor of the Șūr-e Esrāfil newspaper. See: Parvin 1998: Index: Ğahāngīr-Khan Širāzi.

35 Miti-Jenn 32.2-21. 
Julā'i describes the tense atmosphere in Tehran vividly and impressively: ${ }^{36}$ Everybody is suffering from hunger and the cold winter weather, galloping inflation, and the brutality and tyranny of the Qājār rulers. Bread has become extremely expensive, and coal is sold at the price of red gold. Thus light and warmth have left the gatherings of friends and the hearts of people. The situation is made worse by general violence. The inhabitants of Tehran incessantly hear the thundering cannons of the Bāḡ-e Šāh Regiment ${ }^{37}$ and the yelling of the swordsmen of the Silāknur Regiment. ${ }^{38}$ At Meydān-e Tup-k̄āneh, ${ }^{39}$ the slashed bodies of the constitutionalists hang upside down from plane trees.

In the circumstances, it does not surprise that people, having lost their minds ( $p \bar{a}$ az dāyereh-ye ta' aqqol birun godāšteh), assume that they live in the kingdom of jenn and paris (dar molk-e jenn-o parizendegi mi-konid). Their destiny seems to have been put into the hands of soothsayers and geomancers (āyineh-bin-hā o-rammāl-ān). ${ }^{40}$

The main incident of the story happens in the following context: Miti-Jenn, the above-mentioned imaginary being (moujudi kiyāli), appears in the capital. It drives the Qājār despots (mostabeddin) out of their senses and makes the courtiers (dar-bāriyān) go crazy, while giving the suppressed masses some relief. This episode - significantly, the author calls it a mythic fable (afsāneh) - is the main topic of conversation and the principal theme of the short story. Such a characterization leads us back to further reflections on Julā'i’s writing style.

\section{Magical Realism}

The author often describes his writing style as magical realism, and this characterization is well illustrated by the short story Miti-Jenn. On the one hand, the tale is situated in a clearly-defined historical and geographic framework which is depicted in minute detail (Tehran during the Qājār period, especially during the Constitutional Revolution). On the other hand, Julā'i projects a second realm onto this reality-based background with the multilayered episode of an imaginary creature called Miti-Jenn. Irrupting into everyday life, it disturbs the ordinary state of affairs. The boundaries between reality and the imaginary begin to merge.

36 Miti-Jenn 32.22-33.9.

37 Bāğ-e Šāh is situated in western Tehran. During the Qājār period, the rulers frequently resided in this park (Dehkodā 1377/1998).

38 Silāknur: an area situated in the šahrestān Borujerd (Province of Lorestān). The SilākururRegiments were famous for their bravery (Moșāheb 1380/2001).

39 Name of an important place in central Tehran; the old Arg was situated nearby.

40 Miti-Jenn 33.7-9. 
Julā'i, who is deeply interested in a re-evaluation of reality (vāqe iyyat), assumes that this concept has undergone important transformations during the last century. ${ }^{41}$ As lived reality has often been bitter if not almost unbearable, especially for people living in the "East", they long for relief and escape.

According to Julā'i, it is the duty of the artist - whether writer, filmmaker, painter or poet - to develop a new and independent understanding of the world. Ideally, the point of view of the artist differs from that of the public. Hidden behind factual reality lies another level of existence, a parallel world. ${ }^{42}$

Short stories of Julā'i's other than Miti-Jenn reflect this conviction of his. The following two short stories may serve as examples: $\check{S} \bar{a} h-k \bar{a} r$ (The masterpiece) ${ }^{43}$ and Mo jezeh dar bārān (A wonder in the rain). ${ }^{44}$ In both texts, having recourse to the medium of film illustrates Julā'i's understanding of magical realism.

In Šāh-kār, a filmmaker called Mirzā Așgarar-Khan, a highly respected artist of the Nāṣer al-Din Shah era ${ }^{45}$ who had withdrawn from public life for a long time, presents his latest film in a soirée at the royal court of Mohammad 'Ali Shah. ${ }^{46}$ The artist considers this film to be his masterpiece ( $\check{a} \bar{a} h-k \bar{a} r)$.

The film shows the bombardment of the Iranian parliament ('adālat-kāneh) by the Cossack Brigades on 23 June 1908 (2 Tir 1287), on the orders of Mohammad 'Ali Shah. Cannons are thundering as the Cossacks attack the people assembled in front of the Majles. A pall of white smokes rises to reveal dozens of bodies. On the screen, Mirzā Aṣgar-Khan is seen searching for his son who has been killed, together with a great number of other victims.

When Mirzā Așgar-Khan suddenly discovers the body of his child, he jumps into the screen in front of the public and participates personally in the unfolding events. While the Shah orders that the scoundrel be seized, the filmmaker runs to the body of his son, puts his head in his lap, and sheds bitter tears.

Several versions circulated in Tehran about the end of this soirée. One group claimed that Mirzā Aṣgar-Khan - from out of the film - threw a piece of wood at the Shah who had taken cover behind his chair. Others were convinced that Mirzā

41 Interview with Reżā Julā'i published at: http://www.ghabil.com/article.aspx?id=219.

42 Interview with Reżā Julā'i published at: http://www.ghabil.com/article.aspx?id=219:

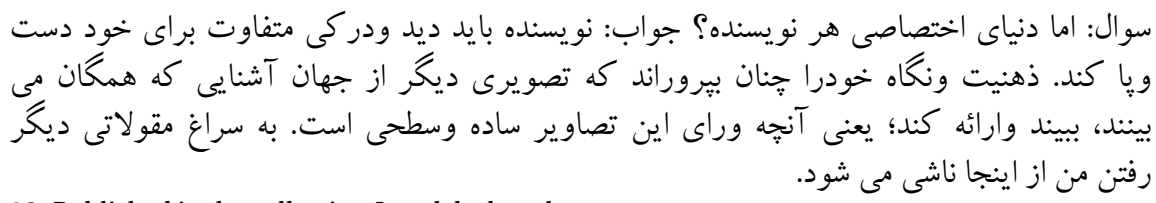

43 Published in the collection Jāmeh be kunāb.

44 Published - as Miti-Jenn - in the collection Tālär-e tarab-kaneh.

45 Nāṣer al-Din Shah, 1831-96, reigned from 1848 to 1896.

46 Moḥammad 'Ali Shah, 1872-1925, reigned from 1907 to 1909. 
Așgar-Khan shot at the king with a pistol. A third group heard how the filmmaker had insulted the Qājār ruler. At the end of the film, Mirzā Aṣgar-Khan loads the body of his son onto his shoulders and walks away. The following morning, he was seen one last time weeping at a newly-dug grave. He disappears afterwards.

Julā'i in Mo'jezeh dar bārān also uses direct participation in a film which is actually running on a screen. ${ }^{47}$ The episode discussed here describes the difficult economic situation in Iran at the beginning of the twentieth century when unemployment was widespread. In a small cinema, a father is watching a film with his son. When - on the screen - work is offered, the father jumps directly into the film. As one of the last spectators, he gets hold of a balloon lifting him up to an ideal abode where work abounds and the sorrows of everyday life are a thing of the past. Before disappearing, the father tells his perplexed child that he would return with enough money to resolve all their difficulties.

This recourse to the medium of film illustrates Julā'i's endeavor to bridge the gap between immediate reality and the imaginary. We encounter the same effort in Miti-Jenn. Here, the mingling of different levels is more complex: At the beginning of the tale, the narrator and Jahāngir-Khan are sitting in their small printing office discussing the latest news. ${ }^{48}$ Jahāngir-Khan alludes to Miti-Jenn whom everybody seems to fear. ${ }^{49}$

Julā'i explains his conviction by starting a meta-discussion on superstitious attitudes. On the one hand, Jahāngir-Khan clearly refutes the belief in supernatural beings such as jenn and paris. People who believe in their existence have not had the advantage of a serious education, and they ignore even the most basic insights of modern science. ${ }^{50}$ On the other hand, however, Jahāngir-Khan accepts that these tales circulate in Tehran and are on everyone's lips.

Confronted with the tense political situation, people attribute every incident which surpasses their own powers to Miti-Jenn, this exceptional creature, who penetrates castles unnoticed and climbs up every wall. And last but not least, MitiJenn helps people achieve their rights. ${ }^{51}$ This last function will be of prime importance.

47 Mo jeze dar bārān (published in Tālār-e țarab-k̄āneh): 131.15-132.24.

48 Miti-Jenn 33-36.

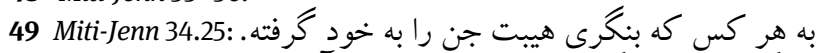

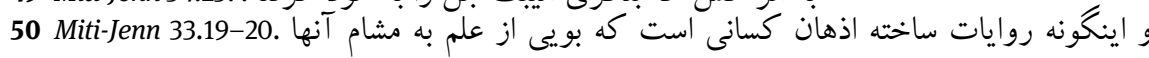

51 Miti-Jenn 33.22-24:

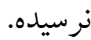

$$
\text { دوادند واو به جاى كه به تاز گیى ظهور كرده آنجه از يد قدرت آنها خارج بود به اين موجود خيالى نسبت مى مي }
$$


From the narrator's perspective, there are no exact boundaries between reality and the imaginary. He asks the reader whether sense perception is indeed reliable when dealing with the external world. ${ }^{52}$ According to the author, an exclusively rational attitude does not allow for extraordinary phenomena to be integrated into a comprehensive world-view. Phantoms ( $a \check{b} b \bar{a} h$, sg. šabaḥ) fleeing in the twilight, voices (așwāt, sg. șawt) heard from the cellar, objects (ašyā) disappearing suddenly, or mysterious lights shining from behind trees would have no place in an exclusively rational understanding.

But Julā'i, once more hiding his real intentions, ${ }^{53}$ explains that in his short story, he is not concerned with the jenn, the childbed-demon called $\overline{\mathrm{A}} \mathrm{l}^{54}$ or a genius named gul. ${ }^{55}$ Rather, his story analyzes the behavior of a handful of men pretending to have thorough knowledge of the sensual world. Society has to follow them, walking behind their banner devoutly beating its breast. ${ }^{56}$ Last but not least, society has to obey them blindly, even if they are misleading them. ${ }^{57}$ Our author, however, is not speaking about things which should not be mentioned (nā-goftani-hā rā bogd̄ārim), such as the conflict between mašruțeh and mašru'eh. His real intentions only emerge through an analysis of Jahāngir-Khan's research on Miti-Jenn.

\section{Jahāngir-Khan's Research on Miti-Jenn}

Being invited to a soirée by a friend, Jahāngir-Khan is offered the possibility of further investigating the existence of Miti-Jenn. The gathering is attended by some guests who claim to have had personal encounters with this unusual creature. ${ }^{58}$ During his research, Jahāngir-Khan experiences several episodes which illustrate the author's endeavor to bridge the gap between different levels of existence. One minute, the reader is confronted with real events, the next, he is plunged into the imaginary.

As the conversation turns more informal (kodemāni), one of the guests - who so far has absolutely refused to believe in the existence of jenn and paris ${ }^{59}$ -

\footnotetext{
52 Miti-Jenn 31.3-4: آيا در مشاهده كار جهان يكسره بر حواس ومنطق خود تكيه داريد؟

53 Miti-Jenn 31.9-13.

54 For the Āl, see: Eilers 1979.

55 For the gul, see: MacDonald/Pellat 1965: 1078:b; Omidsalar/Omidsalar 2003: 393-395.

56 An obvious allusion to the 'Āšurā ceremonies.

57 Miti-Jenn 32.1: وخلايق بايد كه با طناب يوسيده آنان به جاه روند

58 Miti-Jenn 35.5-13.

59 Miti-Jenn 36.13.
} 
describes his visit to Mo in ol-Mamālek's house. ${ }^{60}$ In the garden, he discovered a footprint said to be that of Miti-Jenn. ${ }^{61}$ This footprint, in the shape of a horseshoe, is a recurring element in Julā'i's story. Obviously proving the existence of an imaginary being, it points to a different level of reality, behind the world of everyday manifestations.

The author, however, immediately returns to the real world, explaining that Miti-Jenn had stolen Mo'in ol-Mamālek's jewellery, having shown up at his house some time earlier. The landlord who has seen this unusual being, describes him as a tall man, dressed in black completely and with blue light shining from his eyes. $^{62}$

On his way home at midnight in the company of some of the guests, JahāngirKhan witnesses another incident involving Miti-Jenn. ${ }^{63}$ Their coach suddenly stops en route because a second carriage is blocking the way. Its frightened driver had stopped when he noticed a scuffle taking place in the coach. His passenger, a certain Major Hasan-Khan, was feeling poorly, and a red spot could be seen on his face. Before losing consciousness, the major was just able to utter the name MitiJenn. Questioned about the incident at home, he explains that he felt a hard blow to his face. Jahāngir-Khan, who is making further investigations, is later told that Hasan-Khan had consumed too much opium and been completely intoxicated that evening.

Hajab-'Ali, a cook, takes the journalist immediately back to reality by telling

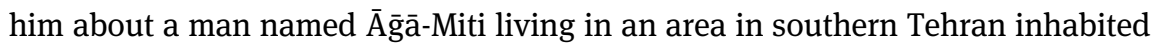
mostly by outlaws, e.g. drug addicts, prostitutes, and procurers. ${ }^{64}$ During further investigations in this rough area, Jahāngir-Khan meets a wretched old man who has been in prison for two years for several crimes including the theft of Mo in olMamālek's jewellery. ${ }^{65}$ In his youth, he had accomplished extraordinary feats. ${ }^{66}$ People are therefore convinced that this Ầ̄ā-Miti is responsible for all the deeds attributed to Miti-Jenn. Jahāngir-Khan sums up the results of his investigations by concluding that Miti-Jenn is nothing but a wretched being addicted to opium, in

60 It most probably refers to Mirzā Abu l-Ḥasan Khan Mo'in ol-Mamālek, an aristocrat from Semnan. During his career of 50 years, he served various Qājār rulers including Nāṣer al-

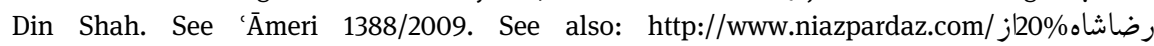

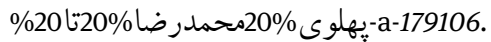

اثر ياى ميتى جن. :Miti-Jenn 36.15

62 Miti-Jenn 36.16-21.

63 Miti-Jenn 37.7-38.18.

64 Miti-Jenn 39.18.

65 Miti-Jenn 40.8, cf. 36.17

66 Miti-Jenn 40.4-5: دست به اعمال محير العقول زده ام ... و كف زنى ها كرده ام. 
fact a Miti-Šire-i (šire: opium). This real person has subsequently been transformed into the fictive Miti-Jenn.

The journalist intends to publish an article on Miti-Jenn. ${ }^{67}$ But the narrator, fearing political repercussions, opposes this idea. His refusal is motivated by leaflets circulating in the capital which are attributed to Miti-Jenn and which contain scathing attacks on the royal court and the despotic rulers. The planned article could therefore create serious problems for their newspaper. If the authorities arrested Jahāngir-Khan, they would interrogate him in prison and eventually ask him: "Your Excellency (scil.: Jahāngir-Khan), are you still unaware of the situation in this kingdom?"68

While this question takes the reader back to the hardship of everyday life, another episode stresses the conflict and, at the same time, the intended ambiguity between reality and the surreal. Visiting a graveyard one night, JahāngirKhan discovers bright lights shining from behind the trees and approaches the scene. ${ }^{69}$ In front of a ruined dome (gombad), beggars, mad-men, and blind and crippled people are celebrating the wedding of a couple from southern Tehran. The description mentions the names of several places where the bridegroom (Pāmenār, Sabzeh-Meydān) and the bride (Gār-Māšin, Meydān-e Pāqāpuq) have their homes. ${ }^{70}$ Thus, Julā'i suspends the boundaries between the fictional and the real once again.

When the assembled guests discover the clandestine observer (rāport-či), they drag Jahāngir-Khan before their white-bearded chief (riš-sefid). ${ }^{71}$ Their master, however, considers him to be innocent. Jahāngir-Khan attends their feast and once more plunges into a fairy world: Rich meals and exquisite drinks are served. Even at the weddings of aristocrats, one would look in vain for something comparable. Julā'i adds that the world has in fact been turned upside down. ${ }^{72}$

The author does not change perspective for no reason but jumps between the real and the imaginary so as to confuse the reader. ${ }^{73} \mathrm{He}$ thus manages to transmit his message. At midnight, the white-bearded chief, who delivers a speech to the assembly, first complains about destiny which made them all infirm and wretched. He then insults the Shah and the despotic rulers who do not allow them to earn an honest livelihood and who expel them from the city under threat of

67 Miti-Jenn 35.14-25.

68 Miti-Jenn 35.21-22: حضرت آقا مكر از اوضاع اين ملك با خبر نيستيد؟

69 Miti-Jenn 44.10-45.25.

70 Miti-Jenn 44.26-45.1.

71 Miti-Jenn 44.22-26.

72 Miti-Jenn 44.26: حقاً كه كار جهان وارونه است

73 Miti-Jenn 45.5-12. 
torture. He also criticizes the constitutionalists as being responsible for the general economic disaster of the country. Even the bridegroom, the bride, and the guests do not escape from his bitter attacks. He expressly calls them parasites (moft-kor).

After this speech, the guests empty their crystal cups. ${ }^{74}$ While Jahāngir-Khan lies in the arms of a wizened woman who caresses him, he observes the others crawling over each other and crying out lustfully. Finally, Jahāngir-Khan dozes off. When he wakes up at daybreak, he finds himself alone in the graveyard. Everybody has left. Only rubbish, discarded clothes, and a tent are reminders of the nocturnal wedding. The community of jenn has disappeared into the soil like water. $^{75}$

\section{The Jenn as Liminal Beings: Foes of Humankind}

The above analysis supports Julā'i's view that another realm of being, not completely separate from factual reality, underlies the world of everyday experience. From time to time, it irrupts into the real world which we perceive through our senses.

Exceptional circumstances, periods of extreme political tension, and liminal situations in general, favor the intrusion of elements of the surreal into everyday life. This other realm is traditionally considered the domain of demonical beings (jenn), and it plays, in fact, an important part in the short story. Miti-Jenn's function calls for some general comments on Islamic demonology.

The term jenn, as a collective, is the standard Arabic expression for ghosts and other similar beings in the entire Muslim world. To this day, jenn are extremely important in almost all sections of Muslim society. Because they are mentioned in the Qur'a $\bar{a} n^{76}$ and by the sunna, to deny their existence is considered an act of unbelief (kofr).

In an unpublished lecture delivered in 1975, Fritz Meier showed that the jenn are morally indifferent: They may be good or bad. ${ }^{77}$ This characteristic distinguishes them from Christian demons which by definition are bad. Depending on their character, jenn manifest themselves to humans as friends or foes. In his short story, Julā'i insists they are both. Taking a closer look at their negative

74 Miti-Jenn 45.16-25.

75 Miti-Jenn 45.25: جماعت جنيان جون آب در زمين فرو رفته بودند

76 Qur'ān, Sura 72, explicitly called “The Jinn”, is entirely dedicated to these beings.

77 Meier 1975. On demonology in the Muslim world, see: Nünlist 2015. 
aspects, ${ }^{78}$ generally speaking, Islam considers the jenn to be liminal beings. They appear in liminal situations, and this they do in three ways:

a) On a spatial level, jenn are associated with all kinds of infertile regions. They people deserts, gorges, ruined buildings, and dirty places (e.g. graveyards, baths, latrines). They live in places at least temporarily abandoned by humans. Their abodes are situated on the boundaries (limen: threshold) of the orderly world (cosmos).

During his research on Miti-Jenn, Jahāngir-Khan goes to some dismal areas in southern Tehran where he meets with prostitutes and drug addicts who live on the fringes of society. ${ }^{79}$ The cemetery in which Jahāngir-Khan attends the nocturnal wedding ceremony is also an area situated on the borders of the orderly world. ${ }^{80}$

b) But the liminal nature of the jenn also has a temporal dimension. Jenn mainly appear in transitional situations. On a micro-cosmic level, they are associated with the darkness of night. Their influence is feared in the context of childbirth, marriage, death, and illness, especially mental illness. ${ }^{81}$ On a macrocosmic level, the New Year period is extremely dangerous. It is considered a period of transition during which the cosmos risks falling back into amorphous chaos. ${ }^{82}$

Julā'i - to a degree - re-activates these age-old beliefs by situating his short story in the context of the Constitutional Revolution, a period of turmoil and general chaos. He concludes his description remarking that, faced with the general disorder during the Constitutional Revolution, people thought they were living among demonical beings, in the kingdom of jenn and paris. ${ }^{83}$

Significantly, Jahāngir-Khan's last and worst series of confrontations with Miti-Jenn happens in the context of the Iranian New Year (nouruz). ${ }^{84}$ The hero, wandering aimlessly through Tehran, looks for a present for his future wife. The narrator tries to reconstruct his adventures in the third and last part of the short story: ${ }^{85}$ When Jahāngir-Khan visits the narrator, he is extremely confused, unshaven, and has red eyes. In short: he resembles a person who has gone $\operatorname{mad}^{86}$ and is

78 For the role of the jenn as friends of humans, see below, part 3.

79 Miti-Jenn 39.1-20.

80 See above: paragraph with footnote 70; and Miti-Jenn 44.10-45.25.

81 Dols 1992: 3, 216-220 and passim.

82 See: Eliade 1989: 65-77; Wensinck 1923: 158-199.

83 Miti-Jenn 33.8: مى ينداشتيد كه در ملك جن ويرى زند كى مى كنيد

84 Miti-Jenn 47.24-25.

85 Miti-Jenn 46-55.

86 Miti-Jenn 46.16-18: جند روز بعد ايشان با ريشى نتراشيده وجشمهاى قرمز وسروضعى تهون مجانين بديدار من آمد. 
hardly able to tell what has happened. ${ }^{87}$ In the Islamic world, madness (jonun) is usually attributed to the intervention of jenn.

c) But the jenn - apart from their appearance in exceptional situations on a spatial and temporal level - are also liminal beings in a third sense: They are guardians of boundaries, and they hinder humans from committing morally prohibited actions. During recent field work in Syria, the anthropologist Gebhard Fartacek observed that jenn intervene when social codes or taboos are ignored. Their intervention calls the culprit to account for his misdeeds. ${ }^{88}$

These observations take us back to certain incidents in the short story which are rationally inexplicable. Miti-Jenn often hurts his victims physically. ${ }^{89}$ Some of Jahāngir-Khan's confrontations with Miti-Jenn illustrate Fartacek's thesis. They make us wonder whether the hero may have disregarded some socially accepted rules and thereby provoked the revenge of the jenn. The following two explanations are particularly interesting:

While Jahāngir-Khan was wandering aimlessly through Tehran, he constantly felt somebody staring at him. ${ }^{90}$ Several times, he is actually able to distinguish the frightening glance of a man observing him directly. Blue columns of light are shining from his eyes. This description recalls the idea of the Evil Eye (Arabic: al- 'ayn; Persian: čašm, čašm-zakm) which is considered a manifestation par excellence of demonical forces. ${ }^{91}$

This spectre (̌̌abah) - it must be identified with Miti-Jenn - finally presents itself once more to Jahāngir-Khan. ${ }^{92}$ After a long pursuit, the hero, caught in a trap, stands in front of an iron door blocking his way. Trying to climb over the door to escape his persecutor, he is suddenly pulled down. Beneath his feet, he discovers the spectre laughing at him mockingly.

87 Miti-Jenn 47.18-23.

88 Fartacek 2010: 157-161.

89 This being was, e.g., made responsible for the attack on Major Hasan-Khan; see above: paragraph containing footnote 63.

90 E.g. Miti-Jenn 48.1-2.

91 For further information on the Evil Eye, see: Šakurzāda/Omidsalar 1987: 44-47.

For the sake of completeness, another incident which happened during Jahāngir-Khan's roaming through the capital in search for a present for his future wife (Miti-Jenn 47.24-49.22) needs to be mentioned: Jahāngir-Khan has entered a jeweller's shop in the Lālehzār-quarter. While he is looking at the bracelets and rings displayed in a show case, he suddenly discovers a tall man completely clad in black standing on the opposite side. This man is observing him expectantly. Jahāngir-Khan is frightened by two columns of blue light emerging from his eyes. On leaving the shop, Jahāngir-Khan resembles someone gone mad (Miti-Jenn 49.20: با حالتى شبيه به مصروعين). Șar' (epilepsy in particular and madness in general) is attributed to attacks by the jenn.

92 Miti-Jenn 51.16-22. 
This spectre addresses Jahāngir-Khan and orders him to keep away from politics. ${ }^{93}$ His warning suggests that active participation in politics is dangerous. A person interfering in politics in Iran - the short story analyses the situation during the Constitutional Revolution - easily transgresses boundaries and thus lives in a dangerous liminal situation. Consequently, he may be exposed to the attacks of the jenn.

The text alludes to the potential danger of political intervention on another occasion. ${ }^{94}$ After the failed attack on Mohammad 'Ali Shah's life, ${ }^{95}$ people just grumble to themselves about the general situation in the country. They do not express their dissatisfaction openly and keep quiet just as their ancestors did. Too often their tongues had been torn out. ${ }^{96}$ Nonetheless, the struggle for freedom is important, but because of its dangerous nature, it is primarily the duty of exceptional beings. ${ }^{97}$ Ordinary people should avoid such activities.

There is, however, a second reason which provokes the intervention of the jenn. At the beginning of his short story, Julā'i describes Jahāngir-Khan as an intellectual (monavvar ol-fekr) with a modern Western technological education. ${ }^{98}$ Jahāngir-Khan repeatedly belittles superstitious beliefs in the existence of supernatural beings, ${ }^{99}$ and so do several other figures. ${ }^{100}$ Apparently, a belief in demonical beings is incompatible with a modern world view. A series of remarks at least suggests this assumption. Because such an attitude openly contradicts convictions which Julā'i formulated elsewhere, it calls for further investigation.

Jahāngir-Khan, no longer able to escape the spectre in front of the iron door, is taught a lesson ('ebrat). ${ }^{101}$ The ghost criticizes Jahāngir-Khan for having exclu-

\footnotetext{
93 Miti-Jenn 52.1:متوقعم كه يلتيك نزنيد

94 Miti-Jenn 41.11-20.
}

95 As a reaction against this attack on his life, Mohammad 'Ali Shah dissolved the newly established parliament (bombardment of the majles: 23 June 1908).

96 Miti-Jenn 41.15-18:

$$
\begin{aligned}
& \text { خلايق در دل كله مند از اوضاع ودر عمل قدمى از قدم برنداشتند كه عافيت را در حفظ زبان واعمال }
\end{aligned}
$$

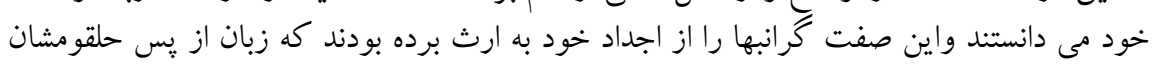

$$
\begin{aligned}
& \text { بيرون كشيده شده بود. }
\end{aligned}
$$

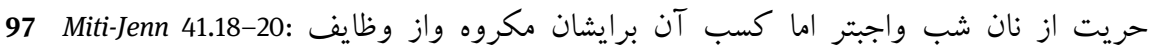

$$
\text { از ما بهتر ان محسوب مئ من شود. }
$$

The expression az-mā-behtarān denotes demonical beings. See: Dehkodā 1377/1998.

98 Miti-Jenn 32.7.

99 Miti-Jenn, e. g. 33.17-21; 34.17-19; 43.4-9.

100 Miti-Jenn, e.g. 36.13f.; 36.25-26.

101 Miti-Jenn 52.9. 
sively intellectual convictions. ${ }^{102}$ By pressing its foot against the iron door, it tries to prove the existence of a level of being which is beyond rational explanation.

Obliged to bow down, Jahāngir-Khan discovers the imprint of a foot (jā-ye pā) on the door. He can feel it with his fingers. Another footstep on the pavement resembles imprints discovered elsewhere, in the houses of notables, on the roofs of buildings, or at places inaccessible to normal creatures, e.g. on gutters. ${ }^{103}$ These footsteps, a leitmotif in the short story, are the general topic of conversation in Tehran.

Although standing in front of the iron door, Jahāngir-Khan sees these footprints, he is still not convinced of their reality. In order to remove any lingering doubts, the spectre first expands until it reaches the top of the door. Immediately afterwards, it shrinks to the height of Jahāngir-Khan's knees. Some moments later, it flies away across the moon. ${ }^{104}$

But before doing so, the spectre heavily slaps Ǧahāngīr-Khan's face twice. ${ }^{105}$ Miti-Jenn reproaches Jahāngir-Khan that he has repeatedly belittled the manifestations of the imaginary. ${ }^{106}$ In so doing, he has rejected the existence of the fictional and therefore deserves to be punished. ${ }^{107}$ The author calls the existence of this other level of reality a scientifically established fact. Anybody ignoring it is punished by the intervention of the jenn.

\section{Miti-Jenn - the Friend of Humans: The Continuing Relevance of Reżā Julā'i's Short Story for an Analysis of More Recent Developments in Iranian Society}

The preceding analysis seemed to take us far away from the present. Initially, we were mainly concerned with the Constitutional Revolution at the beginning of the twentieth century and then turned to Islamic demonology. But Julā'i is not a writer

\footnotetext{
102 Miti-Jenn 52.8:منورالفكرها ديرباورند

103 Miti-Jenn 40.18-22.

104 Winker (1936: 9) describes a comparable scene: An 'ifrit first increases to a considerable height and then sinks down. Finally he disappears under the earth.

105 Miti-Jenn 53.14-18.

106 Miti-Jenn 54.1-2: نر بر احوال خود ثابت قدم بودى اين تِنين امور وهميه را به مسخره نمى كرفتى.

107 Miti-Jenn 53.4-5: آنكس كه خرافات را در بست باطل مى داند به علم اعتقادى ندارد.
} 
of historical stories and novels. His literary œuvre, on the contrary, is of prime importance for the analysis of more recent social developments in Iran.

Interested mainly in the present and the future, Julā'i insisted in an interview that he had no nostalgia for the past. ${ }^{108}$ Concrete historical events only make up twenty percent of his writings and merely constitute the framework of his tales, while eighty percent is pure imagination (kiyāl, takayyol). This use of the imaginary which allows Julā'i to bridge the gap between the past and the present, is well illustrated by an episode at the very end of Miti-Jenn. ${ }^{109}$

The narrator, trying to explain the different experiences during JahāngirKhan's last walk through Tehran from a rational point of view, has to concede that this is nearly impossible. Having recalled the general atmosphere of tyranny in the capital, he alludes to the political and social tensions for which he holds a despotic Shah responsible. In these circumstances, he insists that the appearance of an exceptional creature like Miti-Jenn is absolutely rational. ${ }^{110}$

In their affliction, people consider Miti-Jenn a sign of the approach of the end of time ( $a z$ 'alāyem-e âker oz-zamān). Praying to God, they secretly beg a thousand times each day not to be deprived of this extraordinary creature who all alone bears the burden of the Iranian nation. ${ }^{111}$ Julā'i once more alludes to the prayers of the people. ${ }^{112}$ If every day, he explains, the cold sighs of a desperate nation rose to heaven, they would finally cause a thin fissure in God's throne. Through this fissure, the jenn and paris would descend on earth to help humankind.

By introducing the idea of jenn and paris descending to earth, Julā'i rejects another interpretation. The concept of the end of time recalls the figure of the Mehdi re-establishing a just order on earth where previously, terror and tyranny were omnipresent. ${ }^{113}$ Maybe Miti-Jenn assumes a comparable role by defending

108 Interview with Reżā Julā'i published on: http://www.ghabil.com/article.aspx?id=219, p. 3.

109 Miti-Jenn 54.15-55.10.

110 Miti-Jenn 54.21-23:

در اوضاع واحوالى شبيه به آنجه ملت وشاه مستبد ولوطيها ومعلق زنها وشامورتى بازها يديد آورده بودند، ظهور موجودى آنجنانى منطقى بودو

111 Miti-Jenn 46.4-10:

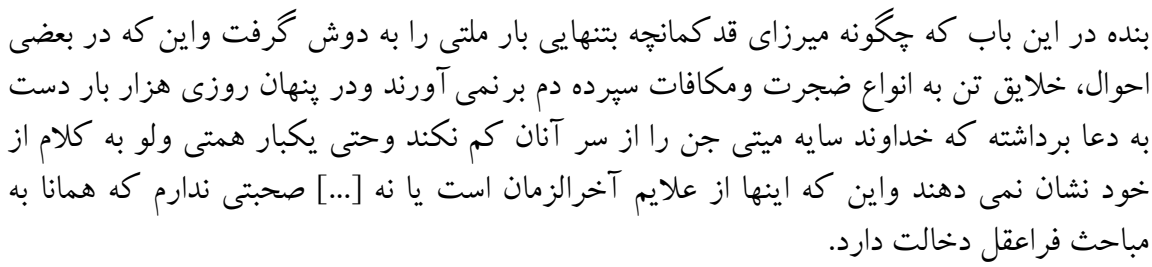

112 Miti-Jenn 54.23-25.

113 For the figure of the Mehdi, see: Halm 2005: 36-39. 
people's rights under the extremely difficult circumstances prevailing during the Constitutional Revolution.

From an exclusively rational point of view - which is unacceptable to the author - we have to ask whether Miti-Jenn has to be identified with the soteriological figure of the Mehdi. Such an explanation may be confirmed by linguistic evidence. ${ }^{114}$ In southern Tehran, e. g. at Meydān-e Šuš or Shah 'Abd ol-'Azịim, the name Mehdi is pronounced Meyti or even Miti. ${ }^{115}$

In the figure of Miti-Jenn, several concepts merge. On the one hand, he assumes the role of the Mehdi appearing at the end of time to re-establish a just state of affairs and to drive away the usurpers. On the other, the author has recourse to Islamic demonology, and he integrates in his short story different elements of this widespread belief.

In conclusion, I would like to highlight an aspect which has passed unnoticed so far. Julā'i mentions several times that the different actors resemble each other. Twice Jahāngir-Khan, clearly embarrassed, says that the demonical creature which appeared to him resembled the narrator. He explicitly compares the hat of the spectre to the one the narrator used to wear. ${ }^{116}$ In a second instance, JahāngirKhan directly likens Miti-Jenn to the narrator. He is even convinced that he has long been acquainted with this imaginary creature. ${ }^{117}$

The possible identity of the main actors, namely the narrator, Jahāngir-Khan, and Miti-Jenn, calls for an explanation. In Islamic demonology, we encounter the conviction that human beings have a qarin, a ra'ìy, a tābi' , a șāhib or a šayțān. ${ }^{118}$ All these expressions denote a sort of double of the individual. In Persian, this idea is expressed by the term ham-zād which refers to a creature born along with the individual. ${ }^{119}$

The word ham-zād does not occur in Julā'i's text. This, however, does not mean that the concept itself is absent from it. Jahāngir-Khan repeatedly insists on

114 The term miti is once vocalized in the text (Miti-Jenn 33.17).

115 I thank Dr. Hamid Hosrawi, University of Zurich, for this information.

116 Miti-Jenn 43.17-19:

بغته شخص سياهيوشى را ديدم كه به طريقه غير معمول جلو آمده شنل سياهى بر دوش و كلاه قابلمه

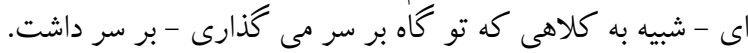

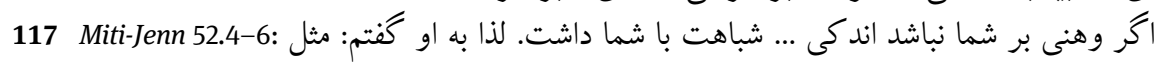
آن كه شمارا مى شناسم.

118 For further information, see Henninger 1963:302 with note 176; Eilers 1979: 64; Dols 1992: 304; Pielow 1998: 48; Fartacek 2010: $60 \mathrm{f}$.

119 Ham-zād: Hedāyat 1963: 42, 86:

$$
\text { و آن جنور است كه جون فراد فيكوندى متولد شود جنى هم با او بوجود مى آيد و با آن شخص همراه مى باشد }
$$

This definition is taken from Borhān 1342/1963. See also Eilers 1979: 36, 38, 51, 63. 
his feeling that somebody is following on his heels, and each time, the expression ham-rāh, ham-rāhi is used. ${ }^{120}$ The underlying idea is the same.

At the end of the story, Julā'i confirms this interpretation. The narrator explicitly presents himself to the reader as Miti-Jenn. ${ }^{121}$ The figure of the narratorMiti-Jenn, evidently a double of the journalist Jahāngir-Khan, was printing leaflets to help people who suffered from tyranny. ${ }^{122}$ He considers it his duty to awaken the Iranian nation.

His task is complicated by the extreme degree of social disunity and political fragmentation (šeddat-e tafarroq-o tašattot). ${ }^{123}$ Because of this disunity, the various political actors in Iran were quarrelling about their inheritance around the deathbed of their native country during the Constitutional Revolution. ${ }^{124}$ This final observation leads one to question whether the appearance of an extraordinary being like Miti-Jenn might indeed resolve the problems and difficulties Iran has had to face more recently-problems and difficulties essentially due to various kinds of disunity.

\section{Bibliography}

'Alik̄āni, Yusuf (2001) Nasl-e Sevvom. Dāstān-nevisi-ye Emruz. Tehran.

Allafi, Mohammad H. (2000): Ein Fenster zur Freiheit: 100 Jahre moderne iranische Literatur drei Autorengenerationen. Frankfurt am Main.

'Āmeri, Hušang (1388/2009): Az Reżā Šāh tā Mohammad Reżā Pahlavi: Mošāhedāt va Kֵāterāt-e Mirzā Javād Kāan 'Āmeri (Mo'in-al-Mamālek). Tehran.

Balaÿ, Christophe / Cuypers, Michel (1983): Aux Sources de la Nouvelle Persane. Paris.

Borhān, Moḥammad Ḥosayn ebn-e Kֵalaf (1342/1963 [1063 h.q./1653]): Borhān-e Qāṭé, edited by Mohammad Mo'in. Tehran.

Dehḱodā, 'Ali-Akbar (1377/1998): Loḡat-nāmeh. $2^{\text {nd }}$ edition. Tehran

Dols, Michel W. (1992): Majnun: The Madman in Medieval Islamic Society. Oxford.

Eilers, Wilhelm (1979): Die Äl, ein persisches Kindbettgespenst. Munich.

Eliade, Mircea (1989): Le mythe de l'éternel retour. Paris.

Fartacek, Gebhard (2010): Unheil durch Dämonen? Geschichten und Diskurse über das Wirken der Ǧinn. Eine sozialanthropologische Spurensuche in Syrien. Vienna.

Halm, Heinz (2005): Die Schiiten. Munich.

Hedāyat, Șādeq (1963): Nirangestān. Tehran.

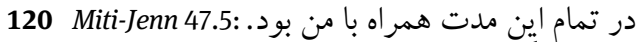

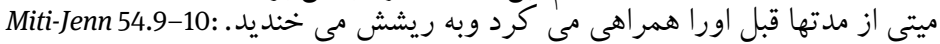

See also Ṣ. Hedāyat's definition in footnote 119: "wa bā ān šaks ham-rāh mi-bāšad".

121 Miti-Jenn 55.9-10.

122 Miti-Jenn 55.1-8.

123 Miti-Jenn 55.6.

124 Miti-Jenn 42.2-6. 
Henninger, Joseph (1963): Geisterglaube bei den vorislamischen Arabern. Vienna.

Julā'i, Reżā (1362/1983): Hekāyat-e Selseleh-ye Pošt-kamānān. Tehran.

Julā'i, Reżā (1368/1989): Jāmeh be Kun-āb. Tehran.

Julā'i, Reżā (1369/1990): Šab-e Ẓolmāni-ye Yaldā-o Ḥadiț-e Dord-kešān. $2^{\text {nd }}$ ed. Tehran.

Julāì, Reżā (1371/1992): Tālār-e Tarab-k̄āneh. Tehran.

Julāì, Reżā (1374/1995): Su'-e Qaṣd be D̄āt-e Homāyuni. Tehran.

Julā'i, Reżā (1376/1997): Jāvedānegān. Tehran.

Julā'i, Reżā (1377/1998): Nastaran-hā-ye Șurati. Tehran.

Julā'i, Reżā (1380/2001): Bārān-hā-ye Sabz. Tehran.

Julā'i, Reżā (1381/2002): Simāb-o Kimiyā-ye Jān. Tehran.

MacDonald, D.B. / Pellat, Ch. (1965): “Ghūl” in: Encyclopaedia of Islam. $2^{\text {nd }}$ ed., edited by P.

Bearman, Th. Bianquis, C. E. Bosworth, E. van Donzel and W.P. Heinrichs. Leiden: 2:1078:b. Meier, Fritz (1975): “Die Stellung des Geisterglaubens im Islam." Paper presented at the XIX.

Deutscher Orientalistentag in Freiburg i.Br. (Manuscript available at the Fritz Meier Nachlass

NL 323: D 4.3.11, Universitätsbibliothek Basel). Basel.

Mir-'Ābedini, Ḥasan (1999): Șad Sāl Dastān-nevisi-ye Irān. Tehran.

Moṣāḥeb, Ḡolam-Ḥosayn (1380/2001): Dä'erat ol-Ma'āref-e Fārsi. Tehran.

Nünlist, Tobias (2005): “Verschobene Zeiten - über den iranischen Erzähler Reżā Jula’i.” Orte.

Schweizer Literaturzeitschrift 139: 47-51.

Nünlist, Tobias (2015): Dämonenglaube im Islam. Berlin.

Omidsalar, Mahmoud / Omidsalar, Teresa P. (2003): “Gul." In Encyclopaedia Iranica, edited by

Ehsan Yarshater et al. New York: 11:393-395.

Parvin, Nāṣer al-Din (1998): Tārih̆-e ruz-nāme-negāri-ye Irāniyān-o digar pārsi-nevisān. 2 vols.

Tehran.

Pielow, Dorothee (1998): Lilith und ihre Schwestern. Düsseldorf.

Šakurzāda, Ebrāhim / Omidsalar, Mahmoud (1987): “Čašm-Zaknm.” Encyclopaedia Iranica, edited

by Ehsan Yarshater et al. 5: 44-47.

Talattof, Kamran (2000): The Politics of Writing in Iran. A History of Modern Persian Literature.

Syracuse.

Wakeman, John (ed.) (1987/1988): World Film Directors. 2 vols. New York.

Wensinck, Arent J. (1923): “The Semitic New Year and the Origin of Eschatology." Acta Orientalia 1: 158-199.

Winker, H.A. (1936): Die reitenden Geister der Toten. Stuttgart.

\section{Internet Sources (last consulted in January 2010)}

Reżā Julā'i’s official website: www.rezajoulaee.com.

Yusef 'Alikāni interview with R. Julā'i: http://sokhan.com/articles.asp?ID=31010.

Interview with R. Julā'i, in: Qābil. Majalle-ye dāstān-o šér. (http://www.ghabil.com/article.aspx?

id=219).

Review of Simāb-o kimiyā-ye jān, from Ḥ. Mir-'Ābedini: http://sokhan.com/articles.asp?

ID $=3690660001$

Entry of Dāriuš Mehrju'i in the "Internet Movie Database": http://www.imdb.com/name/ nm0576529/.

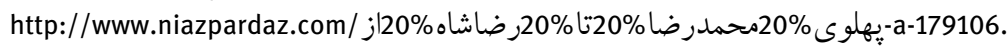

